\title{
Biogeochemical characteristics of a long-lived anticyclonic eddy in the eastern South Pacific Ocean
}

\author{
Marcela Cornejo D’Ottone ${ }^{1}$, Luis Bravo², Marcel Ramos ${ }^{3}$, Oscar Pizarro ${ }^{4}$, Johannes Karstensen ${ }^{5}$, \\ Mauricio Gallegos ${ }^{6}$, Marco Correa-Ramirez ${ }^{7}$, Nelson Silva ${ }^{8}$, Laura Farias ${ }^{9}$, and Lee Karp-Boss ${ }^{10}$ \\ ${ }^{1}$ Escuela de Ciencias del Mar, Pontificia Universidad Católica de Valparaíso, P.O. Box 1020, Valparaíso Chile and \\ Millennium Institute of Oceanography, Valparaíso, Chile \\ ${ }^{2}$ Centro de Estudios Avanzados en Zonas Áridas (CEAZA), Facultad de Ciencias del Mar, Universidad Católica \\ del Norte \& Millennium Nucleus for Ecology and Sustainable Management of Oceanic Islands (ESMOI), Coquimbo, Chile \\ ${ }^{3}$ Departamento de Biología Marina, Facultad de Ciencias del Mar, Universidad Católica del Norte \& Millennium \\ Nucleus for Ecology and Sustainable Management of Oceanic Islands (ESMOI) \&Centro de Estudios Avanzados en \\ Zonas Áridas (CEAZA), Coquimbo, Chile \\ ${ }^{4}$ Department of Geophysics, University of Concepcion, Chile and Millennium Institute of Oceanography, Concepción, Chile \\ ${ }^{5}$ Physical Oceanography, GEOMAR Helmholtz Centre for Ocean Research Kiel, Kiel, Germany \\ ${ }^{6}$ Departamento de Ecología, Pontificia Universidad Católica de Chile, Santiago, Chile \\ ${ }^{7}$ Escuela de Ciencias del Mar, Pontificia Universidad Católica de Valparaíso, P.O. Box 1020, \\ Chile and Instituto Milenio de Oceanografía (IMO), Valparaíso, Chile \\ ${ }^{8}$ Escuela de Ciencias del Mar, Pontificia Universidad Católica de Valparaíso, P.O. Box 1020, Valparaíso, Chile \\ ${ }^{9}$ Departamento de Oceanografía, Centro ciencia de Clima y la Resielcia (CR2) and Instituto Milenio de Oceanografia \\ (IMO), Concepción, Chile \\ ${ }^{10}$ School of Marine Science, University of Maine, Orono, ME 04469, USA
}

Correspondence to: Marcela Cornejo D’Ottone (marcela.cornejo@ucv.cl)

Received: 23 April 2015 - Published in Biogeosciences Discuss.: 2 September 2015

Revised: 15 March 2016 - Accepted: 1 April 2016 - Published: 20 May 2016

\begin{abstract}
Mesoscale eddies are important, frequent, and persistent features of the circulation in the eastern South $\mathrm{Pa}$ cific (ESP) Ocean, transporting physical, chemical and biological properties from the productive shelves to the open ocean. Some of these eddies exhibit subsurface hypoxic or suboxic conditions and may serve as important hotspots for nitrogen loss, but little is known about oxygen consumption rates and nitrogen transformation processes associated with these eddies. In the austral fall of 2011, during the Tara Oceans expedition, an intrathermocline, anticyclonic, mesoscale eddy with a suboxic $\left(<2 \mu \mathrm{mol} \mathrm{kg} \mathrm{kg}^{-1}\right.$ of $\left.\mathrm{O}_{2}\right)$, subsurface layer $(200-400 \mathrm{~m})$ was detected $\sim 900 \mathrm{~km}$ off the Chilean shore $\left(30^{\circ} \mathrm{S}, 81^{\circ} \mathrm{W}\right)$. The core of the eddy's suboxic layer had a temperature-salinity signature characteristic of Equatorial Subsurface Water (ESSW) that at this latitude is normally restricted to an area near the coast. Measurements of nitrogen species within the eddy revealed under-
\end{abstract}

saturation (below $44 \%$ ) of nitrous oxide $\left(\mathrm{N}_{2} \mathrm{O}\right)$ and nitrite accumulation $(>0.5 \mu \mathrm{M})$, suggesting that active denitrification occurred in this water mass. Using satellite altimetry, we were able to track the eddy back to its region of formation on the coast of central Chile $\left(36.1^{\circ} \mathrm{S}, 74.6^{\circ} \mathrm{W}\right)$. Field studies conducted in Chilean shelf waters close to the time of eddy formation provided estimates of initial $\mathrm{O}_{2}$ and $\mathrm{N}_{2} \mathrm{O}$ concentrations of the ESSW source water in the eddy. By the time of its offshore sighting, concentrations of both $\mathrm{O}_{2}$ and $\mathrm{N}_{2} \mathrm{O}$ in the subsurface oxygen minimum zone (OMZ) of the eddy were lower than concentrations in surrounding water and "source water" on the shelf, indicating that these chemical species were consumed as the eddy moved offshore. Estimates of apparent oxygen utilization rates at the $\mathrm{OMZ}$ of the eddy ranged from 0.29 to $44 \mathrm{nmol} \mathrm{L}^{-1} \mathrm{~d}^{-1}$ and the rate of $\mathrm{N}_{2} \mathrm{O}$ consumption was $3.92 \mathrm{nmol} \mathrm{L}^{-1} \mathrm{~d}^{-1}$. These results show that mesoscale eddies affect open-ocean biogeo- 
chemistry in the ESP not only by transporting physical and chemical properties from the coast to the ocean interior but also during advection, local biological consumption of oxygen within an eddy further generates conditions favorable to denitrification and loss of fixed nitrogen from the system.

\section{Introduction}

Mesoscale eddies play a major role in vertical and horizontal transport of heat, salts and other physical, chemical and biological constituents (Chelton et al., 2007; Chaigneau et al., 2008, 2009). In the eastern South Pacific (ESP) Ocean, mesoscale eddies frequently form in the coastal transition zone off central Chile due to the instability of the alongshore currents (Hormazábal et al., 2013; Morales et al., 2010, 2012). These eddies transport water for long distances and over several months across biogeographic boundaries, from the productive Humboldt (Peru-Chile) Current to adjacent oligotrophic waters of the subtropical gyre (Pizarro et al., 2006). While cyclonic eddies transport surface waters and are seen as negative anomalies by altimetry data, anticyclonic eddies, including the Intrathermocline eddies (ITE) are deeper and transport low oxygen and salty subsurface waters from the Equatorial Subsurface Waters (ESSW; Chaigneau et al., 2011).

Although eddies have been considered a net loss of nutrients from the coastal zone (Gruber, 2011), they constitute a nutrient source in the open ocean that stimulates production in oligotrophic regions (McGillicuddy et al., 1998). In addition, eddies introduce spatial heterogeneity in productivity, community structure and particle flux, as has been observed in the Sargasso Sea (McGillicuddy et al., 1998; Sweeney et al., 2003). Impacts of eddies on biogeochemical processes are of particular interest for coastal transition zones of eastern boundary currents, where oxygen minimum zones (OMZs) and eddies interact (Altabet et al., 2012; Stramma et al., 2013). Open-ocean eddies associated with subsurface hypoxic or suboxic conditions have been observed in both the eastern tropical Atlantic and eastern tropical Pacific (e.g., Lukas and Santiago-Mandujano, 2001; Stramma et al., 2014; Karstensen et al., 2015). High surface productivity, downward particle flux and oxygen respiration, combined with sluggish exchange between the eddy interior and surrounding waters, have been proposed as mechanisms leading to the formation of "dead zones" observed within anticyclonic-mode water eddies (Karstensen et al., 2015). Oxygen consumption rates within an eddy can be 3 to 5 times higher than in the surrounding oligotrophic water (Karstensen et al., 2015). Eddies containing hypoxic or suboxic water can become hotspots for nitrogen cycling, including biogenic production of $\mathrm{N}_{2}$ and loss of fixed nitrogen from the system (Altabet et al., 2012; Stramma et al., 2013). Recently, Stramma et al. (2013) suggested that in the eastern tropical Pacific Ocean, coastal mode water eddies are zones of active loss of fixed nitrogen while nitrogen loss associated with older, open-ocean mode water eddies is considerably lower .

In eastern boundary subtropical upwelling systems with a pronounced subsurface OMZ, such as in the ESP, eddies may play an important role in transporting OMZ waters and their microbial communities to the open ocean. The OMZ in the upwelling region of the ESP is associated with Equatorial Subsurface Water (ESSW) that has been transported poleward, from the Pacific Ocean equatorial belt, along the coast with the Peru-Chile undercurrent. The ESSW is characterized by high salinity and nutrient concentrations, low oxygen concentrations and an active, bacterially mediated nitrogen cycling, including production and consumption of the greenhouse gas nitrous oxide $\left(\mathrm{N}_{2} \mathrm{O}\right)$. Intense nitrification, denitrification and nitrous oxide $\left(\mathrm{N}_{2} \mathrm{O}\right)$ production associated with ESSW is generally confined to a narrow coastal band and contributes to net nitrogen loss in this region (Lam and Kuypers, 2011).

Intriguing questions about the role of coastally generated eddies abound: what biogeochemical transformations occur as this volume of water is advected offshore? Do concentrations of dissolved oxygen decrease, increase or remain the same? If changes in dissolved oxygen concentrations occur during transport, what are the other biogeochemical consequences in both surface and subsurface layers? Here, we present results from a study on the physical and chemical characteristics of a single anticyclonic eddy observed $\sim 900 \mathrm{~km}$ offshore, off central Chile. We tracked the eddy back to its region of formation and examined changes in concentration of oxygen and nitrogen species from the time it left the coast to the time it was sampled in the oligotrophic ocean.

\section{Methods}

\subsection{Hydrography and nitrogen data}

Hydrographic data and water samples for analyses of nutrients, $\mathrm{N}_{2} \mathrm{O}$ and surface ${ }^{15} \mathrm{~N}-\mathrm{POM}$ were collected along a transect from Valparaíso, Chile $\left(33^{\circ} \mathrm{S}, 71.6^{\circ} \mathrm{W}\right)$ to Easter Island $\left(28.2^{\circ} \mathrm{S}, 107.4^{\circ} \mathrm{W}\right)$ during the Tara Oceans Expedition (1131 March 2011, Fig. 1; Karsenti et al., 2011). Sampling consisted of 11 vertical profiles using a Sea-Bird 911 equipped with an oxygen sensor (SBE43, sampling rate $24 \mathrm{~Hz}$; Picheral et al., 2014). Due to logistical constraints, the oxygen sensor could not be calibrated on board. It was calibrated at the start of the expedition (July 2009) and a year later (August 2010 during a stopover in Cape Town, South Africa). A third calibration was conducted in September 2011 (during a stopover in Papeete). The sensor showed mean drifts of 0.101 (August 2010) and $0.405 \mu \mathrm{mol} \mathrm{kg}{ }^{-1}$ (September 2011), between successive calibrations. Because oxygen calibrations could not be done routinely, post-cruise validation 

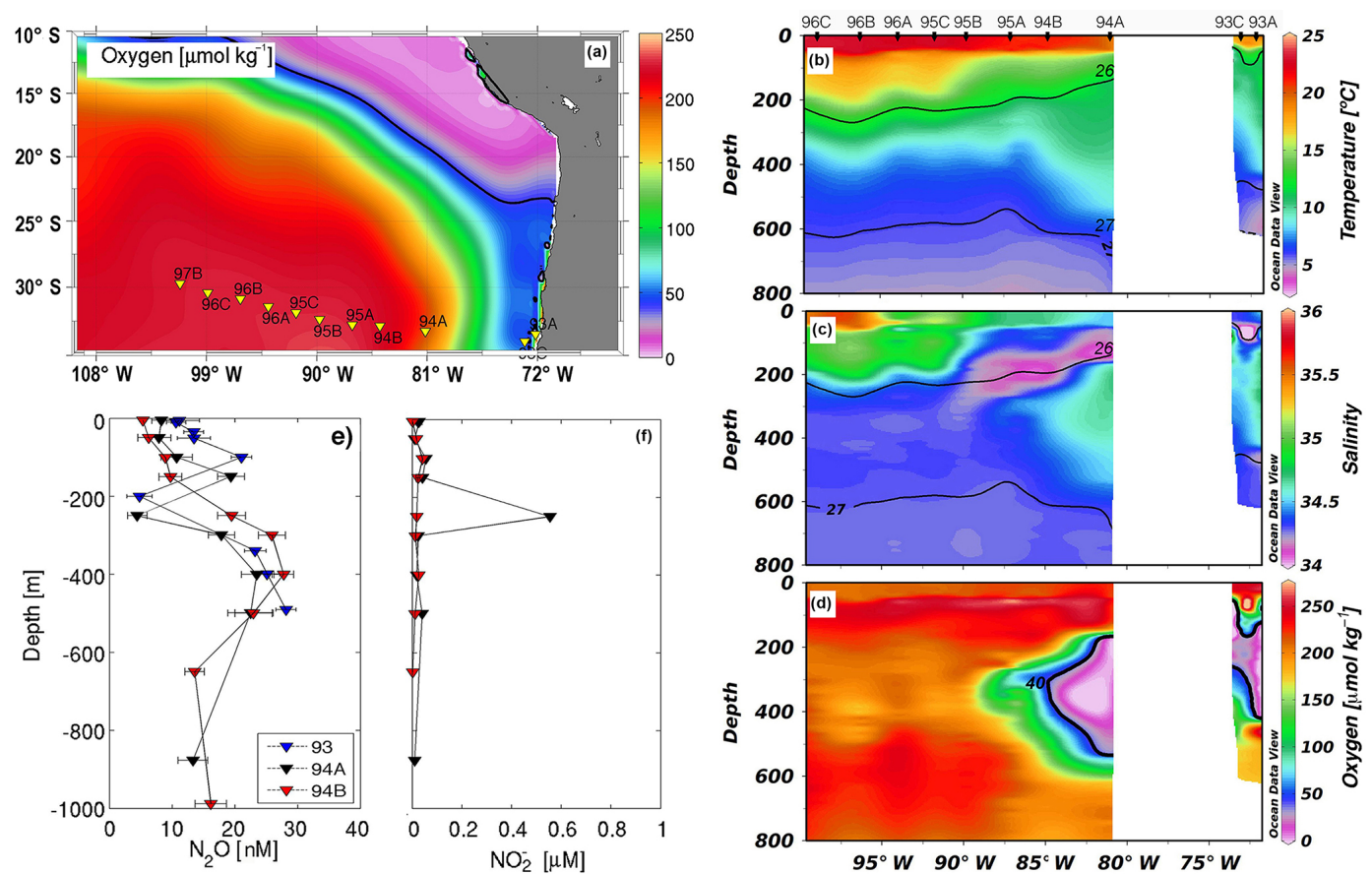

Figure 1. (a) Climatology of dissolved oxygen distributions $\left(\mu \mathrm{mol} \mathrm{kg}{ }^{-1}\right)$ at a depth of $200 \mathrm{~m}$ in the eastern South Pacific Ocean. Yellow triangles indicate locations of stations during the Tara Oceans cruise. Vertical distributions of (b) temperature $\left({ }^{\circ} \mathrm{C}\right)$, (c) salinity and (d) dissolved oxygen along the transect of the Tara Ocean cruise, from coastal water off Chile to the open ocean. Black lines in (b) and (c) indicate the 26.0 and $27.0 \mathrm{~kg} \mathrm{~m}^{-3} \sigma_{t}$ isopycnals. Black line in (d) indicates the isoclines of $40 \mu \mathrm{mol} \mathrm{kg} \mathrm{kg}^{-1}$ of dissolved oxygen. (e) Vertical distribution of $\mathrm{N}_{2} \mathrm{O}$ at Tara stations $093\left(34.0^{\circ} \mathrm{S} / 73.0^{\circ} \mathrm{W}\right.$, blue triangles; TARA_20110312T1637Z_093_EVENT_CAST), 094-A $\left(33.2^{\circ} \mathrm{S} / 81.1^{\circ} \mathrm{W}\right.$, black triangles; TARA_20110316T1152Z_999_EVENT_CAST) and 094-B $\left(32.8^{\circ} \mathrm{S} / 84.8^{\circ} \mathrm{W}\right.$, red triangles; TARA_20110317T1815Z_999_EVENT_CAST). (f) Vertical distribution of $\mathrm{NO}_{2}^{-}$at Tara stations, 094-A (black triangles) and 094-B (red triangles). For a complete detail of the Tara CTD cast please refer to (Picheral et al., 2014).

of oxygen data included comparison of raw oxygen measurements with WOA13 climatology (Garcia et al., 2014) as described by Roullier et al. (2014). For the ESP transect, absolute differences between measured dissolved oxygen (SBE 43) and climatology for the upper $500 \mathrm{~m}$ of the water column averaged $9.1 \mu \mathrm{mol} \mathrm{kg}^{-1}\left(0.03-24.47 \mu \mathrm{mol} \mathrm{kg}^{-1}\right)$ for oceanic stations and $16.7 \mu \mathrm{mol} \mathrm{kg}{ }^{-1}\left(0.06-36.24 \mu \mathrm{mol} \mathrm{kg}{ }^{-1}\right)$ for the coastal stations. Below $850 \mathrm{~m}$, absolute differences between in situ measurements and climatology averaged $6.62 \mu \mathrm{mol} \mathrm{kg}{ }^{-1}\left(0.81-19.08 \mu \mathrm{mol} \mathrm{kg}{ }^{-1}\right)$.

Discrete water samples for $\mathrm{N}_{2} \mathrm{O}$ (in triplicate) and nutrient (in duplicate) analyses were obtained from a rosette equipped with $10 \mathrm{~L}$ Niskin bottles. Samples were collected at 0,50 , $100,150,200,250,300,400,500$, and $900 \mathrm{~m} . \mathrm{N}_{2} \mathrm{O}$ samples $(20 \mathrm{~mL})$ were taken after the inorganic carbon samples, using a tygon tubing to avoid bubble formation. Samples were fixed with $50 \mu \mathrm{L}$ of saturated mercuric chloride and stored in the dark. $\mathrm{N}_{2} \mathrm{O}$ concentrations were determined onshore using a gas chromatograph equipped with an electron capture detector (ECD), following a headspace technique (McAullife, 1971). A four-point calibration curve was determined with air $(0.32 \mathrm{ppm})$ and $\mathrm{N}_{2} \mathrm{O}$ standards of $0.1,0.5$ and $1 \mathrm{ppm}$ (Scotty gas mixture; Air Liquid Co.).
Nutrient samples $\left(\mathrm{NO}_{3}^{-}, \mathrm{NO}_{2}^{-}\right.$and $\left.\mathrm{PO}_{4}^{-3}\right)$ were collected by filtering seawater (GF/F $0.7 \mu \mathrm{m}$ filters); filtrates were stored at $-20^{\circ} \mathrm{C}$ until analysis onshore. Concentrations of $\mathrm{NO}_{3}^{-}, \mathrm{NO}_{2}^{-}$and $\mathrm{PO}_{4}^{-3}$ were measured using a Seal Analytical AA3 AutoAnalyzer (Grasshoff et al., 1983).

\subsection{Eddy identification and tracking}

Presence and position of mesoscale eddies in the region were determined by analyzing weekly maps of anomalies in sea level and geostrophic velocities from the multi-satellite AVISO product (Ssalto/Duacs, http://www.aviso.altimetry.fr/ en/data.html), from April 2010 to September 2011. This gridded, multi-satellite altimeter product provides spatial resolution of $1 / 3^{\circ}$ and allows resolution of eddies with an efolding scale $>40 \mathrm{~km}$ (Chaigneau et al., 2011; Chelton et al., 2011). For eddy tracking, we used the Okubo-Weiss parameter method $(W)$, which evaluates the relative dominance of strain and vorticity (Chelton et al., 2007; Okubo, 1970; Sangrà et al., 2009; Weiss, 1991):

$W=S_{\mathrm{n}}^{2}+S_{\mathrm{s}}^{2}-\omega^{2}$ 
with

$S_{\mathrm{n}}=\frac{\partial u}{\partial x}-\frac{\partial v}{\partial y}$

$S_{\mathrm{s}}=\frac{\partial v}{\partial x}+\frac{\partial u}{\partial y}$

$\omega=\frac{\partial v}{\partial x}-\frac{\partial u}{\partial y}$

where $S_{\mathrm{n}}$ and $S_{\mathrm{s}}$ are the normal and shear components of strain, respectively, and $\omega$ is the relative vorticity.

This approach confirmed that the water mass sampled in station 094-A $\left(30^{\circ} \mathrm{S}, \quad 81^{\circ} \mathrm{W}\right.$; TARA_20110316T1152Z_999_EVENT_CAST;

http://doi.pangaea.de/10.1594/PANGAEA.836473; Fig. 1a) was associated with an eddy. The path of this eddy was reconstructed from its time of origin (28 April 2010) to the time of its decay (29 June 2011) by tracing the eddy center (i.e., the region with highest vorticity) in successive geostrophic fields.

Vertical hydrographic profiles obtained from station 094A (within the identified eddy) were compared with vertical profiles of temperature, salinity and dissolved oxygen concentration collected during other studies in the area and with nearby Argo buoy profiles and climatological information from WOA13 data (Garcia et al., 2014). Data available for the nearest grid $\left(1^{\circ} \times 1^{\circ}\right)$ to station 094-A were used in this analysis.

\subsection{Glider information at the origin of the eddy}

To characterize the properties of water near the time and location of eddy formation we used temperature, salinity and oxygen data from a cross-shore transect $\left(73.0-74.8^{\circ} \mathrm{W}\right.$, $36.5^{\circ} \mathrm{S}$ ) conducted with a Slocum glider (Teledyne Technologies) in June 2010 (Pizarro et al., 2015). The data covered an area that extended to within $160 \mathrm{~km}$ from the presumed starting point of the eddy based on satellite backtracking. The glider was equipped with an optical oxygen sensor (Aanderaa Data Instrument oxygen Optode model 3830). Oxygen sensor calibrations are routinely done at the Physical Oceanography Laboratory, Universidad de Concepción, with a two-point calibration (0 and $100 \%$ of oxygen saturation). Details of the sensor and the physical principles involved in the measurements are described in Körtzinger et al. (2005) and Uchida et al. (2008).

\section{Results and discussion}

\subsection{Hydrography}

A vertical section of temperature, salinity and oxygen, measured along the transect from Valparaíso $\left(33.4^{\circ} \mathrm{S}, 71.6^{\circ} \mathrm{W}\right)$ to Easter Island $\left(27.08^{\circ} \mathrm{S}, 109.3^{\circ} \mathrm{W}\right)$ in March 2011 provides regional context (Fig. 1b, c, d, respectively). A sub-
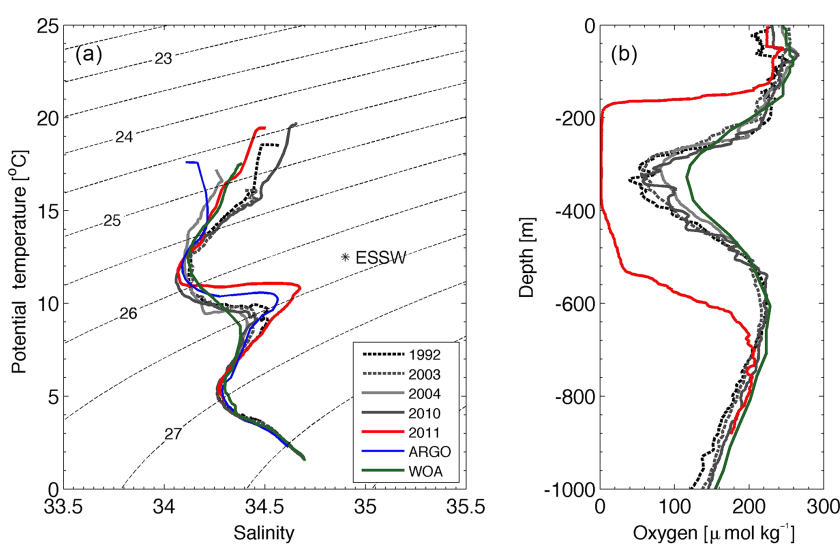

Figure 2. (a) $T-S$ diagram from various sampling programs in the study area; (b) dissolved oxygen profiles at Tara station 094A (red line) and stations in its vicinity from cruises conducted on 1992 (black dashed line), 2003 (gray dashed line), 2010 (thick gray line) and 2004 (thin gray line); from Argo buoys (blue line, without oxygen), and the WOA 2013 climatology (green line). More details on data sources are provided in Table 1.

surface oxygen minimum layer (with dissolved oxygen concentration as low as $1.17 \mu \mathrm{mol} \mathrm{O}_{2} \mathrm{~kg}^{-1}$ ) was detected at station 094-A, $922 \mathrm{~km}$ offshore $\left(30^{\circ} \mathrm{S}, 81^{\circ} \mathrm{W}\right.$, Fig. 1d). Dissolved oxygen concentrations observed at 094-A are anomalous given that at this latitude the boundary of the OMZ (defined as $\mathrm{O}_{2}<44.6 \mu \mathrm{mol} \mathrm{kg}{ }^{-1}$ ) and its core (defined as $\mathrm{O}_{2}<22.3 \mu \mathrm{mol} \mathrm{kg}-1$ ) do not typically extend beyond $\sim 600$ and $\sim 500 \mathrm{~km}$ from the shoreline, respectively (Silva et al., 2009). Suboxic conditions $\left(\mathrm{O}_{2}<10 \mu \mathrm{mol} \mathrm{kg}{ }^{-1}\right)$ are thought to be confined to the shelf region and were reported only in some bottom waters over the continental shelf (Farías, 2003). Climatological data indicate that subsurface water in the vicinity of station 094-A is typically oxygenated (Fig. 1e). According to the above classification of dissolved oxygen concentrations, the OMZ observed at station 094-A has its upper and lower boundaries at depths of 164 and $536 \mathrm{~m}$, respectively, while suboxic conditions were observed between 174 and $421 \mathrm{~m}$ ( $66 \%$ of the OMZ).

The low-oxygen water mass was associated with higher salinities (34.60-34.66) compared to surrounding water (Fig. 1c) and climatology for this region (34.15-34.36, for the years 1965-2012). Historical data from previous cruises conducted along the P06-WOCE transect $\left(32.5^{\circ} \mathrm{S}\right)$ or north of the study region (e.g., $28^{\circ} \mathrm{S}$, Scorpio; Silva et al., 2009; $27^{\circ} \mathrm{S}$, CIMAR 5 cruise; Fuenzalida et al., 2006) do not show such anomalies in physical and chemical conditions at this longitude (Fig. 2a and b). The presence of the anomalous salinity signature observed in this study is supported by an independent Argo float that profiled in the vicinity of 094-A $\left(33.86^{\circ} \mathrm{S}, 79.84^{\circ} \mathrm{W}\right)$ during the Tara Oceans' sampling pe$\operatorname{riod}($ Fig. 2). 
Table 1. Sources of hydrographic data used in this study. The name, location, and distance between the nearest location of the measurements and station 094-A are reported.

\begin{tabular}{llllll}
\hline $\begin{array}{l}\text { Name of } \\
\text { the program }\end{array}$ & Year & Station & $\begin{array}{l}\text { Location } \\
\text { 094-A }[\mathrm{km}]\end{array}$ & $\begin{array}{l}\text { Distance to } \\
\text { of data }\end{array}$ & Kind \\
\hline P06E $(\text { WOCE })^{1}$ & 1992,20032010 & 24 & $32.52^{\circ} \mathrm{S} / 80.64^{\circ} \mathrm{W}$ & 93.1 & Profile \\
Biosope $^{2}$ & 2004 & $\mathrm{STB} 19$ & $33.04^{\circ} \mathrm{S} / 81.18^{\circ} \mathrm{W}$ & 23.8 & Profile \\
${\text { Float } \mathrm{ARGO}^{3}}^{\text {WOA13 }}{ }^{2}$ & 2011 & - & $33.86^{\circ} \mathrm{S} / 79.84^{\circ} \mathrm{W}$ & 137.3 & Float \\
\hline
\end{tabular}

\footnotetext{
${ }^{1}$ http://www.nodc.noaa.gov/woce. ${ }^{2}$ Source: http://www.nodc.noaa.gov/OC5/indprod.html.

${ }^{3}$ Source: http://www.coriolis.eu.org.
}
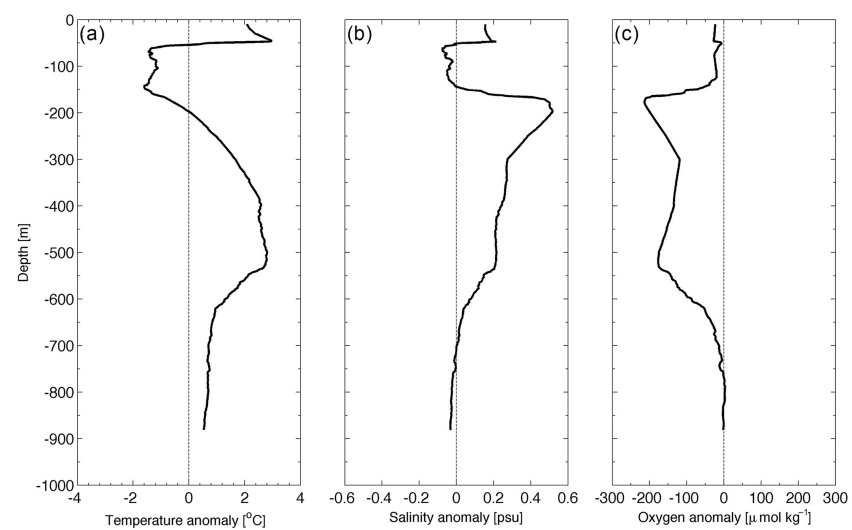

Figure 3. Vertical anomalies of (a) temperature $\left({ }^{\circ} \mathrm{C}\right)$, (b) salinity, (c) dissolved oxygen $\left(\mu \mathrm{mol} \mathrm{kg}^{-1}\right)$ in station 094-A compared with WOA 2013 climatology (range of years for climatology).

Vertical profiles of salinity and temperature anomalies at 094-A show a warm and salty core centered between 230 and $270 \mathrm{~m}$, accompanied by the dome and bowl shapes of the upper and lower thermocline, respectively (Fig. 3). This feature is characteristic of an intrathermocline, anticyclonic eddy (ITE, Xiu and Chai 2011; Chaigneau et al., 2011; Hormazábal et al., 2013). Positive sea-level anomalies (SLA) and associated geostrophic currents further indicate that station 094-A was located close to the center of a mesoscale anticyclonic eddy $\left(\sim 150 \mathrm{~km}\right.$ in diameter), centered at $33.45^{\circ} \mathrm{S}$, $80.85^{\circ} \mathrm{W}$ (Fig. 4 ).

Reconstruction of this mesoscale eddy suggests that it was formed in the coastal transition zone off Concepción $\left(36.09^{\circ} \mathrm{S}, 74.21^{\circ} \mathrm{W}\right)$, approximately $315 \mathrm{~d}$ prior to our sampling at station 094-A, and advected northwest at a mean velocity of $2.4 \mathrm{~cm} \mathrm{~s}^{-1}$, approx. $2 \mathrm{~km} \mathrm{~d}^{-1}$ (Fig. 4). Reconstruction of the eddy's velocity and direction agrees well with previously reported trajectories of eddies in the area (Chaigneau, 2005).

\subsection{OMZ evolution in the eddy}

In the ESP, eddies could frequently transport suboxic water from the coastal OMZ to oceanic regions (Hormazábal et al., 2013). Low-oxygen water masses $\left(\mathrm{O}_{2}<44.6 \mu \mathrm{M}\right)$ have been detected in the middle of the South Pacific Ocean $(2000 \mathrm{~km}$ offshore at $28^{\circ} \mathrm{S}$; Silva et al., 2009), but at the time the authors did not associate these water masses with mesoscale eddies. In the North Pacific Ocean, low concentrations of dissolved oxygen in the subsurface open ocean have been previously described in association with anticyclonic mesoscale eddies (Altabet et al., 2012; Chaigneau et al., 2011; Johnson and McTaggart, 2010; Lukas and Santiago-Mandujano, 2001), and have been attributed to low-oxygen source waters (Lukas and Santiago-Mandujano, 2001) or to local consumption during the transport of an eddy (Karstensen et al., 2015).

To estimate temporal changes in concentrations of dissolved oxygen in the subsurface layer of our sampled eddy, we used underwater glider measurements, collected in June 2010 , at $36.5^{\circ} \mathrm{S} / 74^{\circ} \mathrm{W}$ ( $120 \mathrm{~km}$ from shore). This is the estimated location of the eddy 1 month after its formation and oxygen concentrations of source water are in agreement with those reported for other ITEs in the same region (Hormazábal et al., 2013). Glider measurements of dissolved oxygen showed a well-developed OMZ $\left(\mathrm{O}_{2}<44.6 \mu \mathrm{M}\right.$; Fig. 5) between 104 and $352 \mathrm{~m}$, with a suboxic layer located between 135 and $226 \mathrm{~m}$. We refer to these values as the eddy's "initial" subsurface oxygen concentrations. Dissolved oxygen concentrations were then compared along isopycnals between the estimated location of the eddy's origin and its offshore location at station 094-A (Fig. 6). By the time the eddy reached its offshore location, the OMZ in the eddy was deeper and thicker (located between 164 and $537 \mathrm{~m}$ ) than the OMZ measured in the coastal transition zone, and the lowest dissolved oxygen concentration decreased from $7.34 \mu \mathrm{mol} \mathrm{kg}-1$ at $173 \mathrm{~m}$ to $1.17 \mu \mathrm{mol} \mathrm{kg}^{-1}$ at a depth of $338 \mathrm{~m}$. The suboxic layer of the eddy in the open-ocean was located between 174 and $422 \mathrm{~m}$, almost three times thicker than the suboxic layer of the "source water" (Fig. 6). This suggests that the observed OMZ offshore is a result of both advection of low-oxygen coastal water by an eddy and continuing 


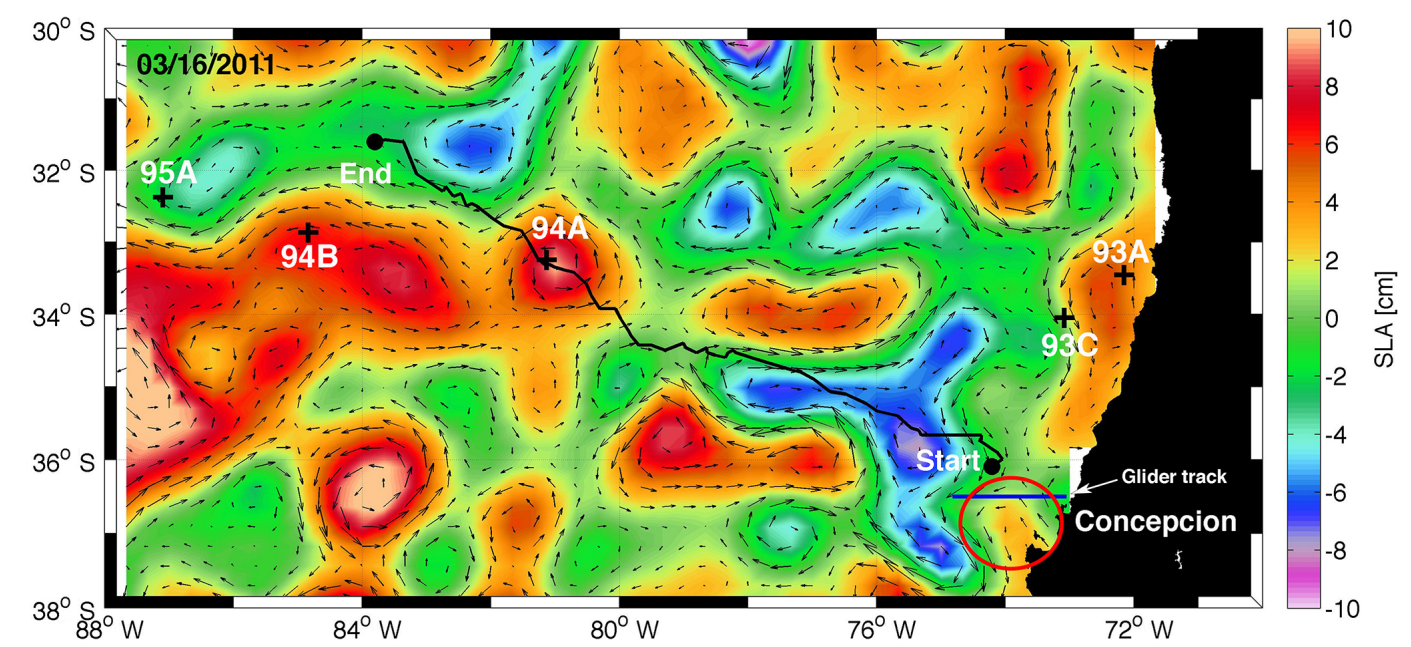

Figure 4. Sea surface hight from satellite data at the time of sampling in Tara station 094-A (March 2011). The position of the sampling stations (black crosses) and estimated eddy trajectory (black line) with start and end locations (black circles) of the trajectory are also indicated. The red circle off Concepción $\left(36^{\circ} \mathrm{S}\right)$ shows the probable eddy generation zone.

biological consumption during its transport. Estimated oxygen consumption rate in the $\mathrm{OMZ}$ of the eddy ranged from 0.29 to $44 \mathrm{nmol} \mathrm{O}_{2} \mathrm{~L}^{-1} \mathrm{~d}^{-1}\left(\sim 0.1-15 \mu \mathrm{mol} \mathrm{O}_{2} \mathrm{~L}^{-1} \mathrm{yr}^{-1}\right)$ in the core of the eddy (Fig. 6), which is quite high compared to previously reported oxygen consumption rates in other OMZs in this depth range (Karstensen et al., 2008). Considering the eddy's area $\left(20 \times 10^{3} \mathrm{~km}^{2}\right.$; transport of ESSW of $\sim 1.38 \mathrm{~Sv}$ ) and the thickness of the layer with dissolved oxygen concentrations $<44.6 \mu \mathrm{M}(373 \mathrm{~m})$, an oxygen deficit of $12.2 \mathrm{Tg}$ is expected in the subsurface eddy's layer. This calculation is likely to underestimate the oxygen deficit since mixing with surrounding oxygen-rich water has not been taken into account here. If the whole sub-saturated oxygen layer of the eddy is considered (from $\sim 80$ to $1000 \mathrm{~m}$ ), the estimated oxygen deficit transported to the oceanic region is even larger. While this crude, back-of-the-envelope calculation of oxygen deficit should be taken with a grain of salt, it highlights the significant influence of eddies on OMZs in the open ocean. When the eddy dissipates, the oxygen deficit in the subsurface layer will be redistributed and will contribute to the overall oxygen budget of the ESP OMZ region.

The area of the "birth" of the studied eddy $\left(\sim 36^{\circ} \mathrm{S}\right)$ has been identified as a hotspot of eddy generation (Hormazábal et al., 2013), with $\sim 5-7$ ITEs that can reach a diameter $>100 \mathrm{~km}$ being formed every year. If the eddy studied here is representative of eddies generated in the $\mathrm{OMZ}$ of the eastern boundary of the Pacific Ocean, between 31 and $36^{\circ} \mathrm{S}$, advection of and continued respiration within oxygen-deficient waters could produce a deficit as high as $60-85 \mathrm{Tg} \mathrm{O}_{2} \mathrm{yr}^{-1}$ within the oceanic region.

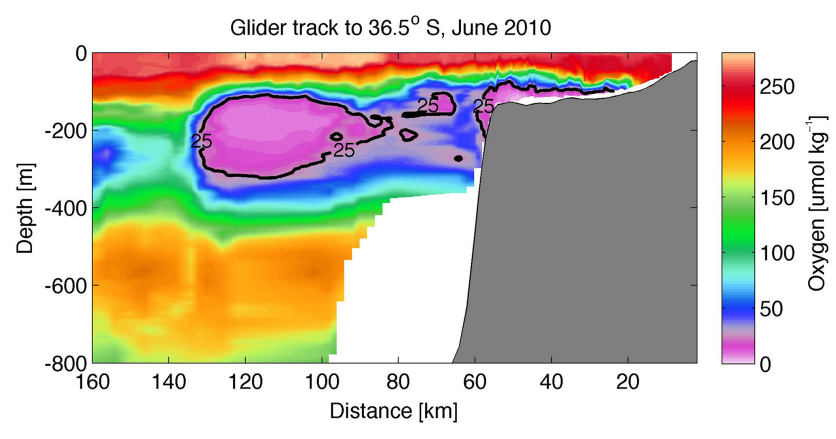

Figure 5. Vertical distributions of dissolved oxygen $(\mu \mathrm{mol} \mathrm{kg}-1)$ in a cross-shore section at $36.5^{\circ} \mathrm{S}$ near the time of eddy formation (June 2010). Black line indicates the isoline of $25 \mu \mathrm{mol} \mathrm{kg}^{-1}$.

\subsection{Subsurface biogeochemical implications of the eddy}

OMZ regions of eastern boundary current systems are considered important with respect to the nitrogen cycle. These are areas where nitrogen is lost due to denitrification and anammox, and are often associated with the buildup of nitrite $\left(\mathrm{NO}_{2}^{-}\right.$; Lam and Kuypers, 2011). Water masses with these features can be advected and the processes enhanced offshore as indicated by the observed accumulation of high subsurface $\mathrm{NO}_{2}^{-}$in anticyclonic coastal eddies (Stramma et al., 2013).

Off the Chilean coast, elevated $\mathrm{NO}_{2}^{-}$concentrations are generally found within the core of the OMZ (Cornejo and Farías, 2012a; Silva et al., 2009). Previous studies conducted in the region of the eddy's formation show that nitrite concentrations in hypoxic waters $\left(<7 \mu \mathrm{mol} \mathrm{O}_{2} \mathrm{~kg}^{-1}\right)$ are $<0.1 \mu \mathrm{M}$ (Cornejo and Farías, 2012b). In the present study, initial oxygen concentrations in the $\mathrm{OMZ}$ of the eddy were 

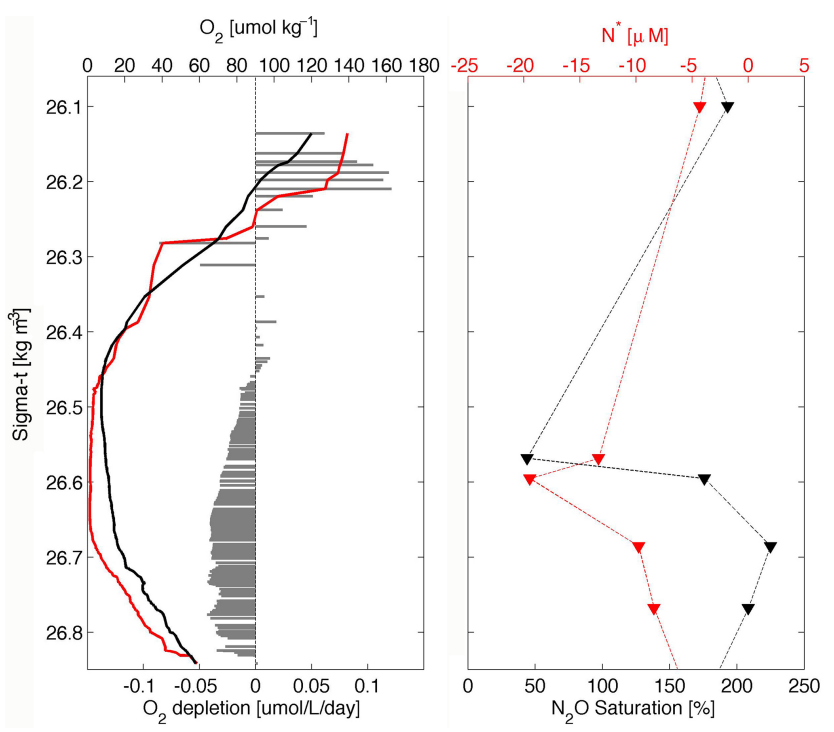

Figure 6. (a) Vertical distribution of Oxygen as a function of $\sigma_{t}$ at Tara station 094-A (within the eddy) in March 2011 (red line) and at the coast in June 2010 (black line). Estimated $\mathrm{O}_{2}$ depletion rates are shown as gray bars, where the vertical dotted line marks zero $\mathrm{O}_{2}$ consumption rate. (b) Vertical distributions of Nitrate deficit $\left(\mathrm{N}^{*}\right)$ and Nitrous oxide saturation (black triangles and line) as a function of $\sigma_{t}$ within the eddy at station 094-A.

low enough to support high denitrification and anammox and, consequently, the accumulation of $\mathrm{NO}_{2}^{-}$. The vertical distribution of $\mathrm{NO}_{2}^{-}$in station 094-A (oligotrophic ocean) shows a subsurface $\mathrm{NO}_{2}^{-}$maximum (up to $0.56 \mu \mathrm{M}$ ) at a depth of $250 \mathrm{~m}$ (Fig. 1f). The apparent buildup of $\mathrm{NO}_{2}^{-}$concentration within the eddy corresponds to a $\mathrm{NO}_{3}^{-}$deficit $\left(\mathrm{N}^{*}\right)$ of $-13.90 \mu \mathrm{M}$ (Fig. 6) relative to surrounding water (determined from the deviation of the $\mathrm{NO}_{3}^{-}: \mathrm{PO}_{4}^{-3}$ molar ratio from the Redfield ratio according to Deutsch et al., 2001), suggesting that conditions in the eddy's anoxic zone were favorable for denitrification. A subsurface water mass with low oxygen concentrations and marked nitrate deficit has been previously observed in the oligotrophic, oceanic water of the EPS, during the Scorpio cruise (Fig. 7, Silva et al., 2009), but other nitrogen species indicative of denitrification were not measured, and tools to link this water mass to eddy activity were not well developed at that time.

Another indication of the existence of anaerobic conditions within the OMZ of the eddy is the presence of a $\mathrm{N}_{2} \mathrm{O}$ consumption layer. This greenhouse gas is produced by nitrification and denitrification under hypoxic conditions and consumed by denitrification under suboxic conditions ( $<8 \mu \mathrm{M}$ of $\mathrm{O}_{2}$; Bonin et al., 1989). The vertical distribution of $\mathrm{N}_{2} \mathrm{O}$ in the eddy (station 094-A) shows a double peak with a supersaturation at the upper and lower boundaries of the subsurface OMZ (up to $224 \%$ ) and subsaturation (44\%) in the upper region of the OMZ core (Fig. 1e), suggesting that both production and consumption of $\mathrm{N}_{2} \mathrm{O}$ occurred in the
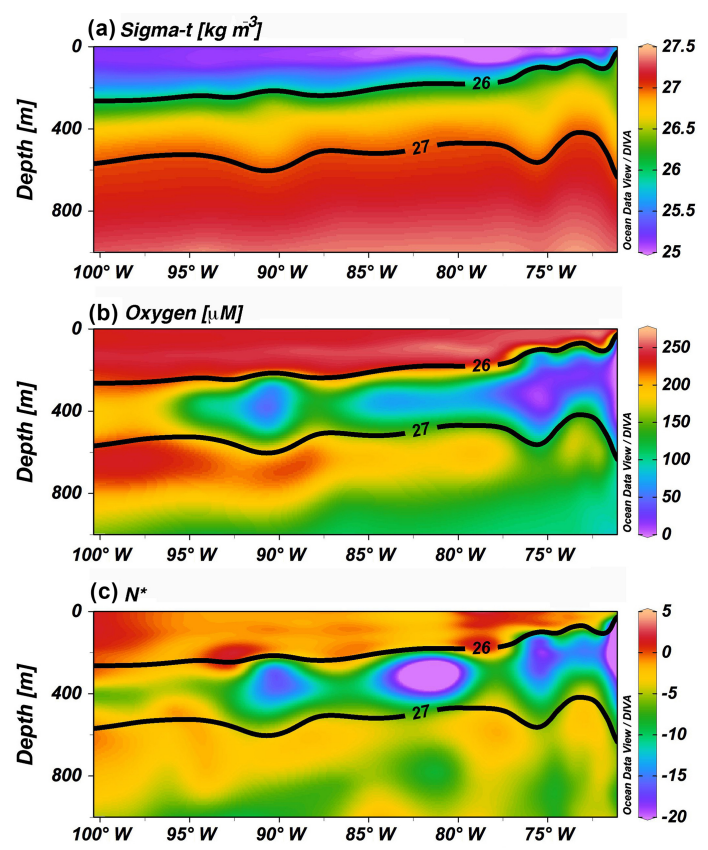

Figure 7. Vertical distributions of $\sigma_{t}$, dissolved oxygen and nitrate deficit $\left(\mathrm{N}^{*}\right.$; according to Deutsch et al., 2001) in a cross-shore transect along $28^{\circ} \mathrm{S}$ in the Eastern Southern Pacific Ocean (72 to $100^{\circ} \mathrm{S}$ ) during Scorpio cruise (June 1967). Black lines refer to $\sigma_{t}$ of 26 and $27 \mathrm{~kg} \mathrm{~m}^{-3}$.

eddy. Layers depleted in $\mathrm{N}_{2} \mathrm{O}$ have been previously observed in different OMZs in coastal environments where denitrification takes place (Cornejo and Farías, 2012a). To the best of our knowledge, this is the first reported $\mathrm{N}_{2} \mathrm{O}$ consumption layer in oceanic subsurface waters of the South Pacific Ocean.

Oxygen concentrations in the area where the eddy was formed are often too high to support significant $\mathrm{N}_{2} \mathrm{O}$ consumption (Cornejo and Farías, 2012b; Cornejo et al., 2015). Thus $\mathrm{N}_{2} \mathrm{O}$ is being accumulated alongshore in the coastal OMZ (up to $25 \mathrm{nM}$ ) and consumed only in bottom waters associated with suboxic conditions. In the absence of direct measurements of $\mathrm{N}_{2} \mathrm{O}$ concentrations at the time of eddy formation, we use the mean coastal $\mathrm{N}_{2} \mathrm{O}$ concentrations $(22.68 \pm 2.99 \mathrm{nM})$ from three previous cruises (FIP; Cornejo et al., 2015) observed at the isopycnal $\sigma_{t}=26.56 \mathrm{~kg} \mathrm{~m}^{-3}$ (depth with $\mathrm{N}_{2} \mathrm{O}$ undersaturation at station 094-A) as the "initial" concentration of $\mathrm{N}_{2} \mathrm{O}$ in the eddy. We estimated a consumption rate of $3.92 \mathrm{nmol} \mathrm{N}_{2} \mathrm{OL}^{-1} \mathrm{~d}^{-1}$ during the time the eddy was advected offshore. This $\mathrm{N}_{2} \mathrm{O}$ consumption rate is half of those reported from incubation experiments conducted at the upper (shallower) boundary of the OMZ off Perú (8.16 nmol L ${ }^{-1} \mathrm{~d}^{-1}$; Dalsgaard et al., 2012). Higher rates might have occurred in the center of the eddy, where more active denitrification is expected. Furthermore, it is likely that we have underestimated $\mathrm{N}_{2} \mathrm{O}$ production since mixing with upper and lower layers that are supersaturated 
with respect to $\mathrm{N}_{2} \mathrm{O}$, was not taken into account in our calculation.

Although $\mathrm{N}_{2} \mathrm{O}$ was sampled from discrete depths, the thickness of the $\mathrm{N}_{2} \mathrm{O}$ consumption layer can be estimated considering that $\mathrm{N}_{2} \mathrm{O}$ consumption does not occur at dissolved oxygen concentrations $>8 \mu \mathrm{M}$ (Bonin et al., 1989). Within the eddy, this layer was $60 \mathrm{~m}$ thick $(210-270 \mathrm{~m})$ meaning that net consumption was at least $\sim 0.15 \mathrm{Gg} \mathrm{N}_{2} \mathrm{O}$ during the offshore transfer. This $\mathrm{N}_{2} \mathrm{O}$ consumption represents only $14 \%$ of the $\mathrm{N}_{2} \mathrm{O}$ accumulation estimated above and below the consumption layer, suggesting that the eddy provided a net supply of $\sim 0.85 \mathrm{Gg}$ of $\mathrm{N}_{2} \mathrm{O}$ to the oceanic region. Observing both production and consumption of $\mathrm{N}_{2} \mathrm{O}$ in the eddy signifies net nitrogen loss, with possible impacts on even global nitrogen and $\mathrm{N}_{2} \mathrm{O}$ balances.

This study provides new evidence that anticyclonic mesoscale eddies play important roles in the biogeochemistry of the ESP (Altabet et al., 2012; Stramma et al., 2013). Previous studies have shown that mesoscale eddies act as hotspots for microbially mediated nitrogen loss via denitrification in coastal water; here we show that open-ocean anticyclonic eddies can play a similar role in parts of the ocean that are far removed from productive coastal waters and their associated OMZs.

Acknowledgements. This study is partly based on data sets gathered by the Tara Oceans Expeditions 2009-2012. We are keen to thank the committed people and the following sponsors who made this singular expedition possible: CNRS, EMBL, Genoscope/CEA, ANR, Agnès B., the Veolia Environment Foundation, Region Bretagne, World Courier, Cap l'Orient, the Foundation EDF Diversiterre, FRB, the Prince Albert II de Monaco Foundation, Etienne Bourgois and the Tara schooner, crew. Moreover, this integrated sampling strategy couldn't have been done without the involvement of École Normale Supérieure, Université Pierre et Marie Curie, Stazione Zoologica, University College Dublin, University of Milan-Bicocca, Institute de Ciences del Mar, University of Bremen, Institute de Microbiologie de la Mediterranée, MNHN, MIT, UofA, Bigelow Institute, Universite Libre de Bruxelles, University of Hawaii. We thank Sarah Searson for providing technical support onboard, Marc Picheral for calibrations of the oxygen sensor and Sabrina Speich for providing satellite images that helped guiding sampling during the cruise. We thank Peter Jumars and John Dolan for his helpful comments and edits. This work is part of the Millennium Scientific Initiative, grant IC 120019. Marcel Ramos and Luis Bravo are grateful for support from Chilean Millennium Initiative (NC120030) grant. Luis Bravo acknowledges support from Posdoctoral-FONDECYT/Chile-3130671. Oscar Pizarro thanks support from FONDECYT 11021041, PFB 37/02 and MI-LOCO (Gordon and Betty Moore Foundation). Johannes Karstensen was supported by the DFG project SFB 754 (http://www.sfb754.de). M. Correa-Ramirez was supported by FONDECYT no. 11130463. Laura Farias was supported by FONDAP program no. 15110009. The authors thank the Goddard Space Flight Center, Greenbelt, MD 20771, USA, for the production and distribution of MODIS data. SLA data were produced by Ssalto/Duacs and distributed by Aviso http://www.aviso.altimetry.fr/en/data.html. This article is contribution number 40 of Tara Oceans.

Edited by: C. P. Slomp

\section{References}

Altabet, M. A., Ryabenko, E., Stramma, L., Wallace, D. W. R., Frank, M., Grasse, P., and Lavik, G.: An eddy-stimulated hotspot for fixed nitrogen-loss from the Peru oxygen minimum zone, Biogeosciences, 9, 4897-4908, doi:10.5194/bg-9-48972012, 2012.

Bonin, P., Gilewicz, M., and Bertrand, J. C.: Effects of oxygen on each step of denitrification on Pseudomonas nautica, Can. J. Microbiol., 35, 1061-1064, 1989.

Chaigneau, A.: Eddy characteristics in the eastern South Pacific, J. Geophys. Res., 110, C06005, doi:10.1029/2004JC002815, 2005.

Chaigneau, A., Gizolme, A., and Grados, C.: Mesoscale eddies off Peru in altimeter records: Identification algorithms and eddy spatio-temporal patterns, Prog. Oceanogr., 79, 106-119, doi:10.1016/j.pocean.2008.10.013, 2008.

Chaigneau, A., Eldin, G., and Dewitte, B.: Eddy activity in the four major upwelling systems from satellite altimetry (1992-2007), Prog. Oceanogr., 83, 117-123, doi:10.1016/j.pocean.2009.07.012, 2009.

Chaigneau, A., Le Texier, M., Eldin, G., Grados, C., and Pizarro, O.: Vertical structure of mesoscale eddies in the eastern South Pacific Ocean: A composite analysis from altimetry and Argo profiling floats, J. Geophys. Res., 116, C11025, doi:10.1029/2011JC007134, 2011.

Chelton, D. B., Schlax, M. G., Samelson, R. M., and de Szoeke, R. A.: Global observations of large oceanic eddies, Geophys. Res. Lett., 34, L15606, doi:10.1029/2007GL030812, 2007.

Chelton, D. B., Schlax, M. G., and Samelson, R. M.: Global observations of nonlinear mesoscale eddies, Prog. Oceanogr., 91, 167-216, doi:10.1016/j.pocean.2011.01.002, 2011.

Cornejo, M. and Farías, L.: Following the $\mathrm{N}_{2} \mathrm{O}$ consumption in the oxygen minimum zone of the eastern South Pacific, Biogeosciences, 9, 3205-3212, doi:10.5194/bg-9-3205-2012, 2012a.

Cornejo, M. and Farías, L.: Meridional variability of the vertical structure and air-sea fluxes of $\mathrm{N}_{2} \mathrm{O}$ off central Chile $\left(30-40^{\circ} \mathrm{S}\right)$, Prog. Oceanogr., 92-95, 33-42, doi:10.1016/j.pocean.2011.07.016, 2012b.

Cornejo, M., Murillo, A. A., and Farías, L.: An unaccounted for $\mathrm{N}_{2} \mathrm{O}$ sink in the surface water of the eastern subtropical South Pacific: Physical versus biological mechanisms, Prog. Oceanogr., doi:10.1016/j.pocean.2014.12.016, 2015.

Dalsgaard, T., Thamdrup, B., Farías, L., and Peter Revsbech, N.: Anammox and denitrification in the oxygen minimum zone of the eastern South Pacific, Limnol. Oceanogr., 57, 1331-1346, doi:10.4319/lo.2012.57.5.1331, 2012.

Deutsch, C., Gruber, N., Key, R. M., and Sarmiento, J. L.: Denitrification and $\mathrm{N}_{2}$ fixation in the Pacific Ocean, Global Biogeochem. Cy., 15, 483-506, 2001.

Faías, L.: Remineralization and accumulation of organic carbon and nitrogen in marine sediments of eutrophic bays: the case of the Bay of Concepcion, Chile, Estuar. Coast. Shelf Sci., 57, 829841, doi:10.1016/S0272-7714(02)00414-6, 2003. 
Fuenzalida, R., Schneider, W., Blanco, J. L., Garcés-Vargas, J., and Bravo, L.: Sistema de corrientes Chile-Perú y masas de agua entre Caldera e Isla de Pascua, Com. Ocean. Nac., 2006.

Garcia, H. E., Locarnini, R. A., Boyer, T. P., Antonov, J. I., Baranova, O. K., Zweng, M. M., Reagan, J. R., and Johnson, D. R.: World ocean atlas 2013, Volume 3, Dissolved Oxygen, Apparent Oxygen Utilization, and Oxygen Saturation, 2014.

Grasshoff, K., Ehrhardt, M., and Kremling, K.: Methods of seawater analysis, edited by: Grasshoff, K., Kremling, K., and Ehrhardt, M., Verlag Chemie, 1983.

Gruber, N.: Warming up, turning sour, losing breath: ocean biogeochemistry under global change, Philos. T. R. Soc. A., 369, 198096, doi:10.1098/rsta.2011.0003, 2011.

Hormazábal, S., Combes, V., Morales, C., Correa-Ramirez, M. A., Di Lorenzo, E., and Nuñez, S.: Intrathermocline eddies in the coastal transition zone off central Chile, 2013.

Johnson, G. C. and McTaggart, K. E.: Equatorial Pacific $13{ }^{\circ} \mathrm{C}$ Water Eddies in the Eastern Subtropical South Pacific Ocean*, J. Phys. Oceanogr., 40, 226-236, doi:10.1175/2009JPO4287.1, 2010.

Karsenti, E., Acinas, S. G., Bork, P., Bowler, C., De Vargas, C., Raes, J., Sullivan, M., Arendt, D., Benzoni, F., Claverie, J.-M., Follows, M., Gorsky, G., Hingamp, P., Iudicone, D., Jaillon, O., Kandels-Lewis, S., Krzic, U., Not, F., Ogata, H., Pesant, S., Reynaud, E. G., Sardet, C., Sieracki, M. E., Speich, S., Velayoudon, D., Weissenbach, J., and Wincker, P.: A holistic approach to marine eco-systems biology, PLoS Biol., 9, e1001177, doi:10.1371/journal.pbio.1001177, 2011.

Karstensen, J., Stramma, L., and Visbeck, M.: Oxygen minimum zones in the eastern tropical Atlantic and Pacific oceans, Prog. Oceanogr., 77, 331-350, 2008.

Karstensen, J., Fiedler, B., Schütte, F., Brandt, P., Körtzinger, A., Fischer, G., Zantopp, R., Hahn, J., Visbeck, M., and Wallace, W.: Open Ocean dead zone in the tropical North Atlantic Ocean, Biogeosciences, 12, 1-9, doi:10.5194/bg-12-1-2015, 2015.

Körtzinger, A., Schimanski, J., and Send, U.: High quality oxygen measurements from profiling floats: A promising new technique, J. Atmos. Ocean. Technol., 22, 302-308, 2005.

Lam, P. and Kuypers, M. M. M.: Microbial Nitrogen Cycling Processes in Oxygen Minimum Zones, Annu. Rev. Mar. Sci., 3, $317-$ 345, doi:10.1146/annurev-marine-120709-142814, 2011.

Lukas, R. and Santiago-Mandujano, F.: Extreme water mass anomaly observed in the Hawaii Ocean Time-series, Geophys. Res. Lett., 28, 2931-2934, 2001.

McAullife, C.: GC determination of solutes by multiple phase equilibration, Chem. Technol., 1, 46-51, 1971.

McGillicuddy, D., Robinson, A., Siegel, D., Jannasch, H., Johnson, R., Dickey, T., McNeil, J., Michaels, A., and Knap, A.: Influence of mesoscale eddies on new production in the Sargasso Sea, Nature, 395, 263-266, 1998.

Morales, C. E., Loreto Torreblanca, M., Hormazabal, S., CorreaRamírez, M., Nuñez, S., and Hidalgo, P.: Mesoscale structure of copepod assemblages in the coastal transition zone and oceanic waters off central-southern Chile, Prog. Oceanogr., 84, 158-173, doi:10.1016/j.pocean.2009.12.001, 2010.

Morales, C. E., Hormazabal, S., Correa-Ramirez, M., Pizarro, O., Silva, N., Fernandez, C., Anabalón, V., and Torreblanca, M. L.: Mesoscale variability and nutrient-phytoplankton distributions off central-southern Chile during the upwelling season:
The influence of mesoscale eddies, Prog. Oceanogr., 104, 17-29, doi:10.1016/j.pocean.2012.04.015, 2012.

Okubo, A.: Horizontal dispersion of floatable particles in the vicinity of velocity singularities such as convergences, Deep-Sea Res., 17, 445-454, 1970.

Picheral, M., Searson, S., Taillandier, V., Bricaud, A., Boss, E., Stemmann, L., Gorsky, G., and Consortium, Tara Oceans Coordinators Tara Oceans Expedition, P.: Vertical profiles of environmental parameters measured from physical, optical and imaging sensors during Tara Oceans expedition 2009-2013, Pangaea, doi:10.1594/PANGAEA.836321, 2014.

Pizarro, G., Montecino, V., Astoreca, R., Alarcón, G., Yuras, G., and Guzmán, L.: Variabilidad espacial de condiciones bio-òpticas de la columna de agua entre las costas de Chile insular y continental. Primavera 1999 y 2000, Cienc. Tecnol. Mar., 29, 45-58, 2006.

Pizarro, O., Ramírez, N., Castillo, M., Cifuentes, U., Rojas, W., and Pizarro-Koch, M.: Underwater glider observations in the oxygen minimum zone off central Chile, B. Am. Meteorol. Soc., doi:10.1175/BAMS-D-14-00040.1, 2015.

Roullier, F., Berline, L., Guidi, L., Durrieu De Madron, X., Picheral, M., Sciandra, A., Pesant, S., and Stemmann, L.: Particle size distribution and estimated carbon flux across the Arabian Sea oxygen minimum zone, Biogeosciences, 11, 4541-4557, doi:10.5194/bg-11-4541-2014, 2014.

Sangrà, P., Pascual, A., Rodríguez-Santana, Á., Machín, F., Mason, E., McWilliams, J. C., Pelegrí, J. L., Dong, C., Rubio, A., Arístegui, J., Marrero-Díaz, Á., Hernández-Guerra, A., Martínez-Marrero, A., and Auladell, M.: The Canary Eddy Corridor: A major pathway for long-lived eddies in the subtropical North Atlantic, Deep-Sea Res. Pt. I, 56, 2100-2114, doi:10.1016/j.dsr.2009.08.008, 2009.

Silva, N., Rojas, N., and Fedele, A.: Water masses in the Humboldt Current System: Properties, distribution, and the nitrate deficit as a chemical water mass tracer for Equatorial Subsurface Water off Chile, Deep-Sea Res. Pt. II, 56, 1004-1020, doi:10.1016/j.dsr2.2008.12.013, 2009.

Stramma, L., Bange, H. W., Czeschel, R., Lorenzo, A., and Frank, M.: On the role of mesoscale eddies for the biological productivity and biogeochemistry in the eastern tropical Pacific Ocean off Peru, Biogeosciences, 10, 7293-7306, doi:10.5194/bg-10-72932013, 2013.

Stramma, L., Weller, R. A., Czeschel, R., and Bigorre, S.: Eddies and an extreme water mass anomaly observed in the eastern south Pacific at the Stratus mooring, J. Geophys. Res.-Ocean., 119, 1068-1083, 2014.

Sweeney, E. N., McGillicuddy, D. J., and Buesseler, K. O.: Biogeochemical impacts due to mesoscale eddy activity in the Sargasso Sea as measured at the Bermuda Atlantic Timeseries Study (BATS), Deep-Sea Res. Pt. II, 50, 3017-3039, doi:10.1016/j.dsr2.2003.07.008, 2003.

Uchida, H., Kawano, T., Kaneko, I., and Fukasawa, M.: In situ calibration of optode-based oxygen sensors, J. Atmos. Ocean. Technol., 25, 2271-2281, 2008.

Weiss, J.: The dynamics of enstrophy transfer in two-dimensional hydrodynamics, Physica D, 48, 273-294, 1991.

Xiu, P. and Chai, F.: Modeled biogeochemical responses to mesoscale eddies in the South China Sea, J. Geophys. Res., 116, C10006, doi:10.1029/2010JC006800, 2011. 